\title{
Working
}

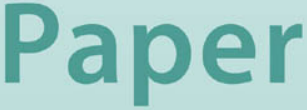




\section{Inclusive Growth, Institutions, and the Underground Economy}

Anoop Singh, Sonali Jain-Chandra, and Adil Mohommad 
This page intentionally left blank

(C) International Monetary Fund. Not for Redistribution 


\title{
IMF Working Paper
}

Asia and Pacific Department

\author{
Inclusive Growth, Institutions, and the Underground Economy ${ }^{1}$ \\ Prepared by Anoop Singh, Sonali Jain-Chandra, and Adil Mohommad
}

February 2012

\section{This Working Paper should not be reported as representing the views of the IMF.} The views expressed in this Working Paper are those of the author(s) and do not necessarily represent those of the IMF or IMF policy. Working Papers describe research in progress by the author(s) and are published to elicit comments and to further debate.

\begin{abstract}
Worldwide protests against the perceived lack of economic opportunity and failure of governance have refocused attention on the need for inclusive growth and strong institutions. In developing countries, large informal economies limit state capacity to deliver governance and strong institutions, which in turn discourages participation in and expansion of the formal economy. This paper analyzes the determinants of the underground economy, with particular emphasis on the role of institutions and the rule of law. We find that when businesses are faced with onerous regulation, inconsistent enforcement and corruption, they have an incentive to hide their activities in the underground economy. Empirical analysis suggests that institutions are a more important determinant of the size of the underground economy than tax rates.
\end{abstract}

JEL Classification Numbers: O43, H2, H26

Keywords: underground economy, shadow economy, institutions

Authors’ E-Mail Addresses:sjainchandra@imf.org, amohommad@imf.org

\footnotetext{
${ }^{1}$ The authors wish to thank Rhoda Weeks-Brown, Victor Thuronyi, and Melissa Tullis from the IMF's legal department for extensive discussions and for contributing the Box on the IMF's role in combating underground economies. We would also like to thank Rupa Duttagupta and Sanjeev Gupta for comments on an earlier version of this paper that was presented at the World Justice Forum, which was a worldwide gathering hosted by the World Justice Project. All remaining errors remain ours.
} 


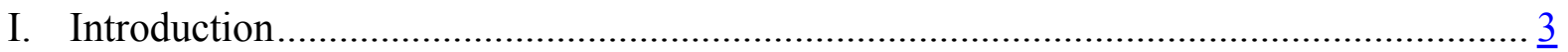

II. Measuring the Size of the Underground Economy ........................................................ 4

III. Determinants of the Size of the Underground Economy: Key Results from the Literature

IV. Relationship Between the Underground Economy and Institutions:

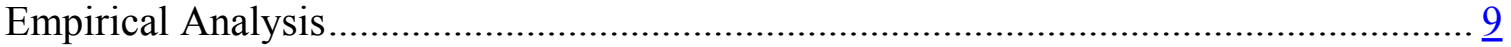

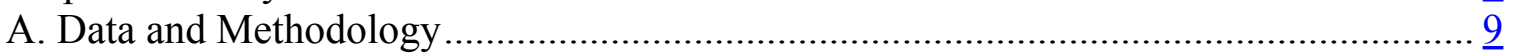

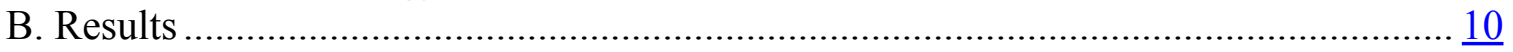

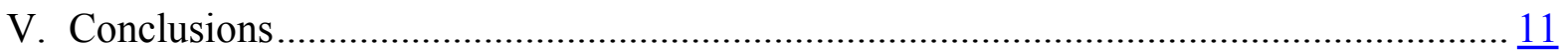

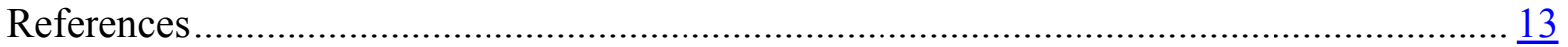

Box

1. Role of the IMF in Reducing the Size of the Underground Economy............................... $\underline{5}$

Figures

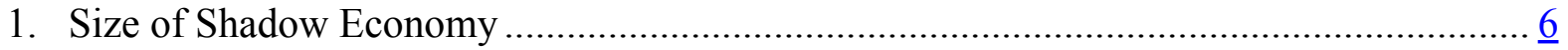

2. Size of Shadow Economy in 2006: By Economic Status ............................................... $\frac{7}{7}$

3. Size of Shadow Economy in 2006: By Region..........................................................

4. Size of Shadow Economy and Regulatory Burden........................................................ $\frac{8}{2}$

5. Size of Shadow Economy and Overall Governance ................................................... $\frac{10}{10}$

6. Size of Shadow Economy and Rule of Law ............................................................. 10

Table

1. Determinants of the Size of the Shadow Economy ……................................................... 11 


\section{INTRODUCTION}

1. The global surge in public protests against perceptions of bad governance and lack of inclusive growth are a reminder of the importance of developing strong institutions on the one hand, and of expanding the benefits of the formal economy to encourage economic growth and opportunity on the other. The two challenges are interlinked: good institutions depend on ample state capacity, which in turn depends on bringing economic activity into the ambit of the formal sector. A large informal economy limits state capacity, which may hinder institutional development, in turn discouraging expansion of the formal sector and limiting the benefits of a formal economy to relatively few participants, discouraging potential economic growth, and wider economic opportunities.

2. Large underground economies pose problems for policy making: a vicious cycle can be set off, as governments with large informal or underground economies may raise tax rates to make up revenues, encouraging further enlargement of the underground economy. This may erode the institutional capacity of the government even more. Fragile states are at a heightened risk of falling into this viscous circle. Moreover, large informal economies render official statistics unreliable and incomplete, complicating the formulation of informed policies. In this "bad" equilibrium, benefits of a formal economy such as property rights protection and access to credit markets are not widely available, which may discourage economic growth and deny economic opportunities to many.

\section{The underground economy, ${ }^{2}$ which includes both illegal and legal activities,} constitutes a significant portion of the economy in a number of countries. Smith (1994) defines the underground economy as the "market-based production of goods and service whether legal or illegal, that escape detection in the official estimates of GDP." However, we follow recent studies that adopt a narrower definition of the underground economy, "which includes all market-based legal production of goods and service that are deliberately concealed from public authorities to avoid the payment of income, value added or other taxes, to avoid payment of social security contributions, having to meet certain legal labor market standards, such as minimum wages, maximum working hours, and safety standards, and complying with certain administrative procedures" (Schneider, Buehn, and Montenegro, 2010).

\section{However on the positive side, a large informal sector may be viewed as the} nursery of future economic growth within the formal economy. This is particularly important when viewed from a development perspective, since poor and emerging countries have much larger shares of informal activity than do rich countries. What links underdevelopment and the shadow economy?

\footnotetext{
${ }^{2}$ Also variously known as the informal/shadow/parallel economy.
} 
5. De Soto (2000) links the problem of underdevelopment with a key institutional weakness, namely that much of the potentially productive capital in poor countries is outside the system of formal property rights. Unlike in countries with mature property rights systems where capital can be leveraged extensively for productive activity, in poor countries it is often very difficult to establish clear rights to property in the first instance, let alone enjoy its benefits such as the capacity to leverage, and the protections afforded by a formal property rights system. The productive capacity of the economy is restricted due to this fundamental institutional weakness, therefore wider participation in the formal economy is hindered, encouraging enclave-like development that benefits the few and leaves the many out.

\section{In De Soto's view, the establishment of institutions that create (and protect)} property rights is the key that can unlock the potential for growth contained within the informal sector. Emerging economies in particular have been playing a more central role in boosting global growth, and the large size of the informal sector in these economies suggests that even higher rates of growth are potentially achievable.

7. In examining the determinants of the size of the shadow economy, several studies place importance on the centrality of institutions, and linked the size of the shadow economy more broadly to various measures of institutional development. This paper seeks to build on this approach and is structured as follows. First, some methods to estimate of the size of the underground economy are discussed and these estimates are analyzed. Next, the paper discusses the determinants of the underground economy, with particular emphasis on the role of institutions and the rule of law. The paper also examines the role of IMF in combating the growth of informalization (see Box 1).

\section{Measuring THE Size OF THE UNDERgROUnd ECONOMY}

\section{Estimating the size of the informal economy is a challenge as the purpose of} operating in it is often to avoid detection and countries may lack the capacity to monitor underground activity. While there are no direct measures of the size and composition of the underground economy, a number of indirect methods have been proposed, although each of these has drawbacks. The methods to estimate the size of the underground economy are (Schneider 2004; Schneider, Buehn, and Montenegro, 2010):

- Currency demand approach: Since most transactions in the underground economy are conducted in cash, this approach estimates the size of the underground economy from the excess demand for cash.

- $\quad$ Electricity demand approach: assumes that electricity usage is a good physical indicator of economic activity, and estimates the growth of the underground economy based on the difference between growth rate of electricity consumption and the official GDP growth. 


\section{Box 1. The Role of the IMF in Reducing the Size of the Underground Economy}

Given the central role of institutions in preventing the growth of underground economies, and more importantly in catalyzing long- term economic growth, institutional development must take center stage. A strong culture of the rule of law, government credibility and strong legal and judicial framework is a critical priority as it forms the basis for good institutions. Also it is important to give priority to the establishment and consolidation of economic institutions, which in turn have a powerful impact on macroeconomic stability, access to and security of property rights, and free trade. The IMF has been involved in strengthening economic institutions in the context of both the provision of surveillance advice and technical assistance (TA) to the membership. The IMF has been at the forefront of the reform of the financial regulatory and supervisory frameworks in the aftermath of the global financial crisis. Also in order to directly combat the problem of the underground economy, the IMF has been supporting members in areas of tax reform and money laundering.

Improving Tax Governance. The IMF's role in fiscal reforms related to reducing the size of the underground economy focuses mainly on improving the tax system. Specifically, the IMF carries out a substantial program of technical assistance in tax policy, tax administration, and drafting of tax legislation. This technical assistance seeks to establish tax regimes for small businesses that involve minimum discretion, hence reducing the scope for corruption, and employ tax accounting rules that minimize the compliance burden on businesses. The IMF also works on reforms related to the drafting of tax procedure codes and implementation of tax administration reforms that support simplified registration procedures. A one-stop shop allows a small business to register without having to go to a multitude of government offices to obtain the necessary business licenses. The IMF's work in this area is coordinated with that of the IFC, which facilitates tax and other administrative reforms to create a more supportive climate for small business.

Combating Money Laundering and the Financing of Terrorism. Recognizing that macroeconomic policy execution is impaired by the existence of unaccounted economic transactions generated in the informal or illegal sectors, the IMF addresses a number of issues related broadly to underground economies. The primary role is to provide technical assistance to members on money laundering and counter terrorist finance policy, and on larger governance and institutional issues when large illicit sectors are thought to have an impact on financial or economic stability. These activities have dual objectives related to reducing the size of underground economies: increasing the ability of governments to identify the source of all assets (including tax fraud), and reducing the size of the cash basis of an economy if it interferes with the ability to identify the source of funds in the economy. Specifically, the IMF implements a broad program of technical assistance designed to help members build capacity in and strengthen AML/CFT law (Anti-Money Laundering - Combating the Financing of Terrorism), legal framework, financial intelligence units, training programs designed to improve on-site inspection procedures for banks and regulators, and implementing a risk based approach to supervision ${ }^{3}$. IMF-supported TA under AML/CFT has taken place in countries such as Bangladesh, Cambodia, Lao PDR, Mongolia, Guinea, Lesotho, The Gambia, China, Syria, Iran, Mauritania, Mauritius, Moldova, Nigeria, the Kyrgyz Republic, Turkmenistan, and the West Bank and Gaza.

\footnotetext{
${ }^{3}$ For additional information, see: IMF, AML/CFT Methodology with FATF $40+9$ Recommendations, Interpretive Notes and Best Practices, June 2009.
} 
- Labor force approach: estimates the growth of the underground economy based on the decline in labor participation, assuming a constant labor participation rate.

- Multiple indicators multiple causes model (MIMIC model): estimates the size of the shadow economy based on multiple observed variables that are presumed to cause it, including the share of direct taxes, the size of the government, tax rates, the regulatory burden, and GDP per capita.

\section{These approaches to measuring the size of the informal economy suggest} that it is sizable in a number of countries (Figure 1). Estimates based on the above estimation methods for 2006 suggest that the shadow economy in most advanced countries ranges from 14-16 percent of GDP, whereas in the case of emerging market countries the range is 32-35 percent of GDP (Figure 2). Underground economies are much larger in Latin America, Central America, and Africa, often greater than 40 percent of GDP. In contrast, in the Middle East and Developing Asia they range between 2535 percent of GDP (Figure 3).

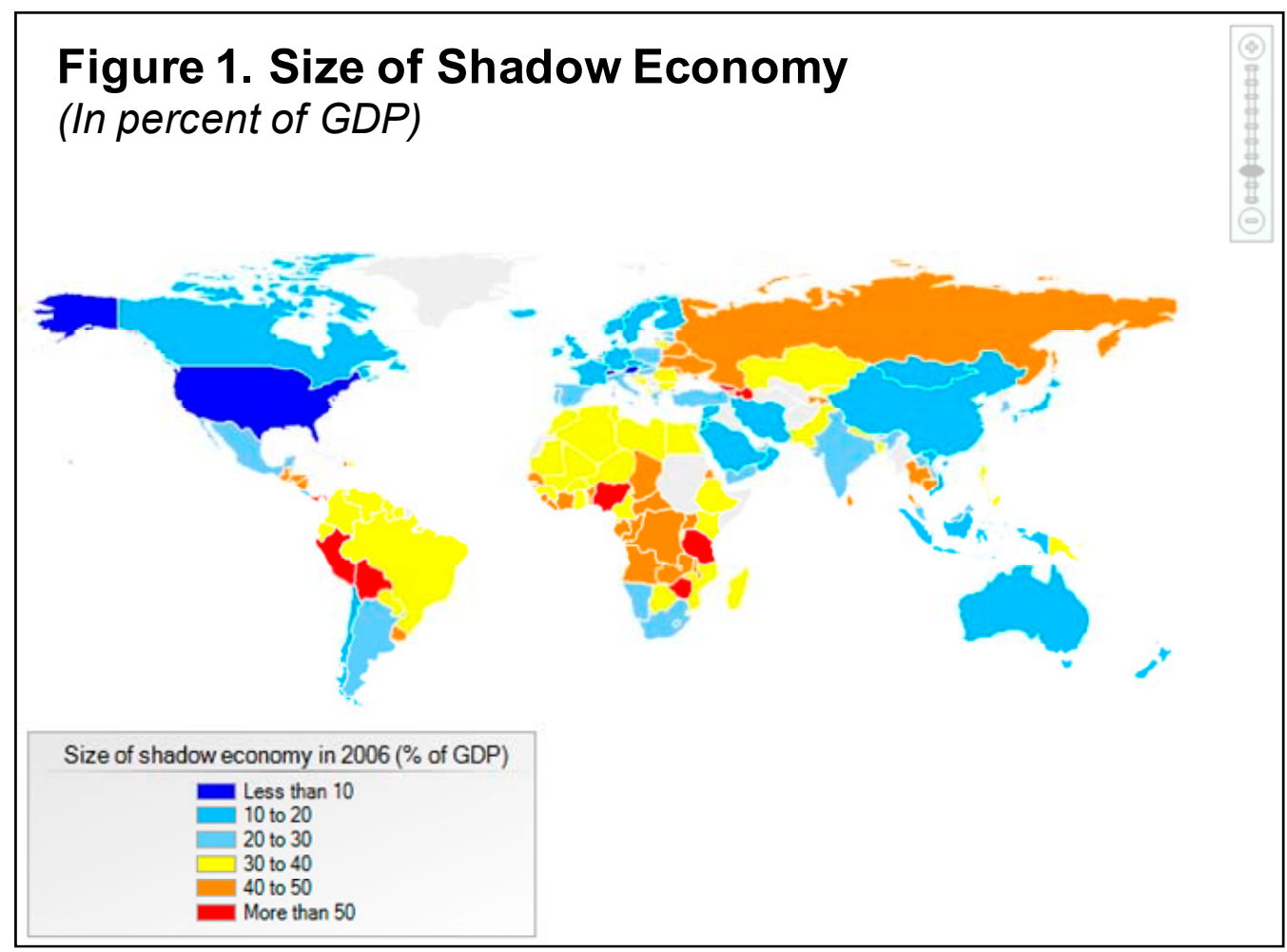



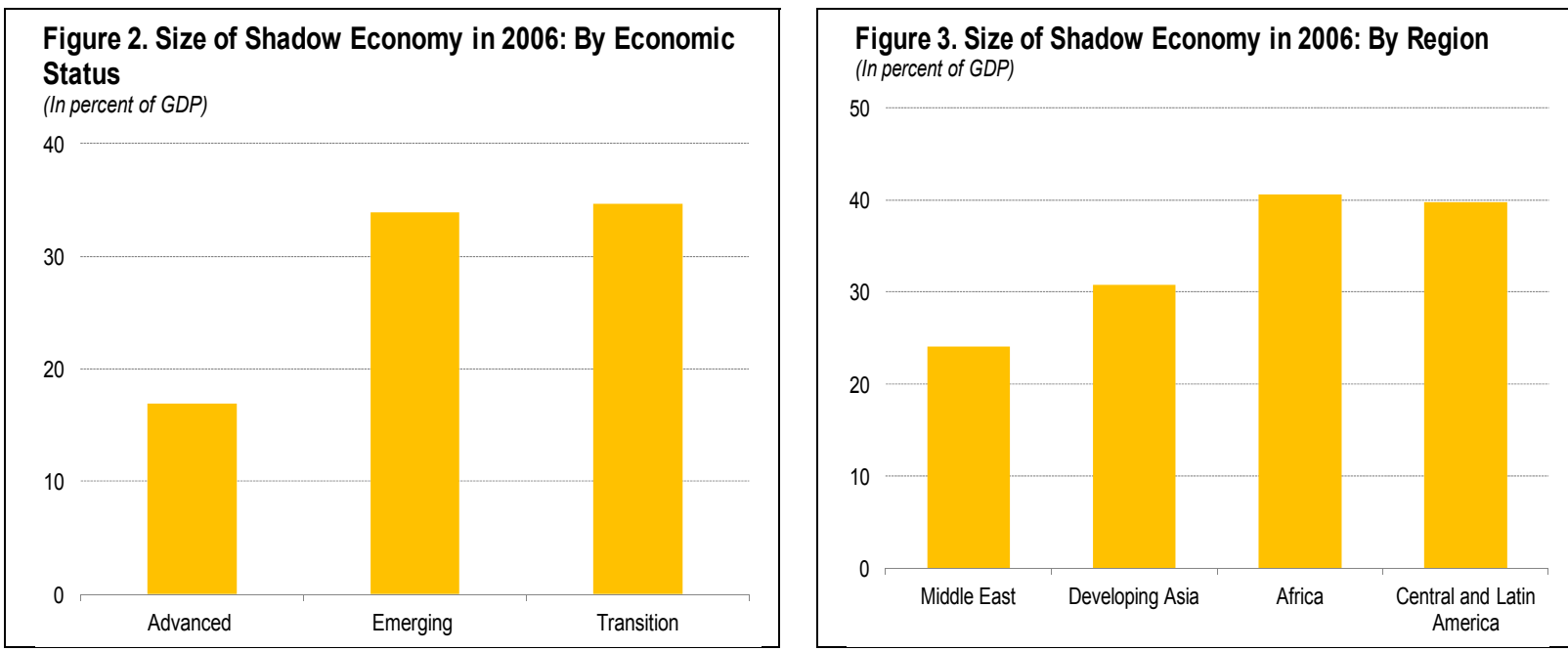

\section{DETERMINANTS OF THE SIZE OF THE UNDERGROUND ECONOMY: KEY RESULTS FROM THE LITERATURE}

10. There is considerable debate on the role of the burden of taxation in leading to increased underground economic activity. One strand of the literature finds that a more burdensome tax regime (including onerous tax rates and administration) is a key driver that leads to an increase in the share of the underground economy, as firms move underground to evade taxes and boost profits. Estimates show that if the tax burden as perceived by firms (measured by the Global Competitiveness Survey) becomes more onerous (by one point on a scale of 1 to 7 ), the size of the shadow economy rises by 11.7 percentage points (Johnson, Kaufmann, and Zoido-Lobaton). In contrast, Freidman and others (2000) find that higher taxes are associated with a smaller underground economy. Specifically, raising taxes by one point (on a scale of 1 to 5, Heritage Foundation measure of tax rates) leads to a 9 percent fall in the size of the underground economy. The contention is that the higher tax rates lead to stronger revenues and better public goods provision, including a more robust legal environment, thereby encouraging firms to operate in the official sector.

\section{Another strand of the literature argues that political, economic, and social} institutions ${ }^{4}$ are the main drivers of increased underground economic activity. Using data from the 1990s for 69 countries, Friedman and others (2000) find that higher taxes are not associated with a larger unofficial economy; rather more bureaucracy, higher corruption and weaker legal environments are correlated with a larger unofficial economy. In particular, the regulatory burden faced by workers and firms is a more important factor that determines the size of the underground economy. Regulatory burden includes costs related to complying

\footnotetext{
${ }^{4}$ Institutions are defined as the formal and informal constraints on political, economic, and social interactions (North, 1990).
} 
with license restrictions and leads to increased costs for firms, which may encourage the move to the shadow economy. Indeed, more regulation is correlated with a larger shadow economy (Figure 4), as a one point worsening of the regulation index (as measured by the Heritage Foundation) is associated with a 12 percent increase in the size of the underground economy (Friedman and others, 1999).

\section{Cumbersome labor market}

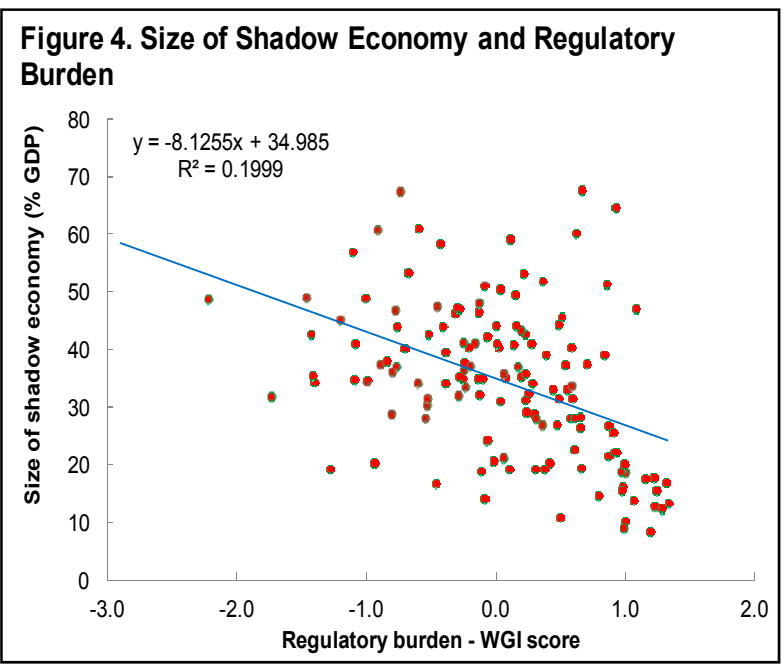

restrictions often lead to an increase in the size of informal employment and thereby the underground economy. The International Labor Organization estimates that more than 70 percent of workers in developing countries are outside the official economy, even though the share of the underground economy is much lower around 35 percent of GDP. Overly stringent labor market regulations have the unintended consequence of encouraging more informal labor arrangements as they raise the cost of hiring for firms. Labor regulations are designed in many cases to restrict hiring workers on flexible contracts, to place limits on maximum hours worked, and to create barriers to firing workers. Analysis using the World Bank's Doing Business database suggests that restrictions on hiring and firing intended to protect workers have instead discouraged firms from hiring in the formal labor market, as compliance tends to be expensive and cumbersome (World Bank, 2004). Instead, firms hire informal workers, pay them under the table and avoid providing health insurance and other benefits. The World Bank study finds that reforms that work well to create jobs include: increasing the length and scope of term contracts, introducing apprentice wages, allowing flexible working hours, and removing administrative approvals for dismissals.

\section{Another drawback of operating in the informal sector is the loss of access to the} formal financial sector for firms and individuals. In many developing countries, less than half the population has an account with a financial institution and in some countries less than one in five households do. This lack of access to finance traps firms in low productivity operations and perpetuates inequality as poor individuals rely on their own limited resources to finance education or start businesses. Since the lack of access to finance is often the critical mechanism behind both persistent income inequality and slow economic growth, financial sector reforms that promote broader access to financial services should be key. Government policies should focus on building sound financial institutions, encouraging competition, and establishing sound prudential regulation to provide the private sector with appropriate incentive structures and broaden access (World Bank, 2008). Governments should make lending attractive to banks by strengthening creditor rights, enabling secturitized lending, and raising interest rate ceilings. The IMF and World Bank jointly prepare a comprehensive and in-depth analysis of a country's financial sector under the 
Financial Sector Assessment Program (FSAP). The FSAP provides an assessment of both the stability of the financial sector, with emphasis on the soundness of the banking and other financial sectors, and the development aspects of the financial sector, which focuses on the quality of the legal framework and financial infrastructure.

\section{RELATIONSHIP BETWEEN THE UNDERGROUND ECONOMY AND INSTITUTIONS: EMPIRICAL ANALYSIS}

\section{A. Data and Methodology}

\section{This section empirically analyzes the determinants of the size of the unofficial} economy using a more comprehensive and recent dataset than the papers discussed in the last section. The key empirical question is the extent to which weaknesses in institutional quality create the room for underground economic activity. However, large underground economies and weak institutions can be mutually reinforcing in theory, and institutions cannot be considered exogenous. From a policy perspective, it is important to gauge whether weak institutions lead to larger underground economies or whether the reverse effect predominates. To do this, this paper employs an instrumental variable regression in which a set of exogenous variables related to geographical and historical factors are used as they have shown to have influenced institutional formation. Using this methodology, we can isolate and estimate the contribution of poor institutions in creating large underground economies.

\section{The analysis uses data on around $\mathbf{1 0 0}$ countries, and includes advanced} countries, emerging markets, and developing countries. The dependant variable is the size of the shadow economy, which is estimated in Schneider, Buehn, and Montenegro (2010) based on the methodologies outlined in the previous section. Other independent variables include the top marginal income tax rate (Fraser Institute), real per capita GDP in (World Bank WDI database), and CPI inflation (IMF's IFS database).

\section{The measures of institutional quality are drawn from the widely used World} Bank's Governance database, which is based on Kaufmann, Kraay, and Zoido-Lobaton (1999) and Kaufmann, Kraay, and Mastruzzi (2009). ${ }^{5}$ This data comprise six composite indicators which measure perceptions of institutional quality: ${ }^{6}$ voice and accountability, political stability and the absence of violence, government effectiveness, regulatory quality,

\footnotetext{
${ }^{5}$ We also consider alternative measures of institutional quality, namely the Heritage Foundations's Index of Economic Freedom.

${ }^{6}$ These aggregate indicators are based on hundreds of individual variables measuring various dimensions of governance and institutional quality, based on views of household and firm survey respondents. Then the paper uses an Unobserved Components Model (UCM) to combine these individual indicators into the six composite measures of governance. The composite measures of governance generated by the UCM are in units of a standard normal distribution, with mean zero, standard deviation of one, and running from approximately -2.5 to 2.5 , with higher values corresponding to better institutional outcomes.
} 
the rule of law, and control of corruption. The overall institutional quality or governance indicator is the average of these six composite indicators. A higher value of these indicators corresponds to superior institutions. All these measures are highly correlated so only one can be used in the empirical analysis at a time to avoid misleading inference.

\section{B. Results}

\section{The size of underground economies is influenced predominantly by the quality} of institutions. As discussed in the previous section, a number of studies find that the underground economy accounts for a larger share of national income when there is more corruption and when the rule of law is weak. Figures 5 and 6 show that the size of the underground economy declines as the overall institutional quality and the rule of law improve.
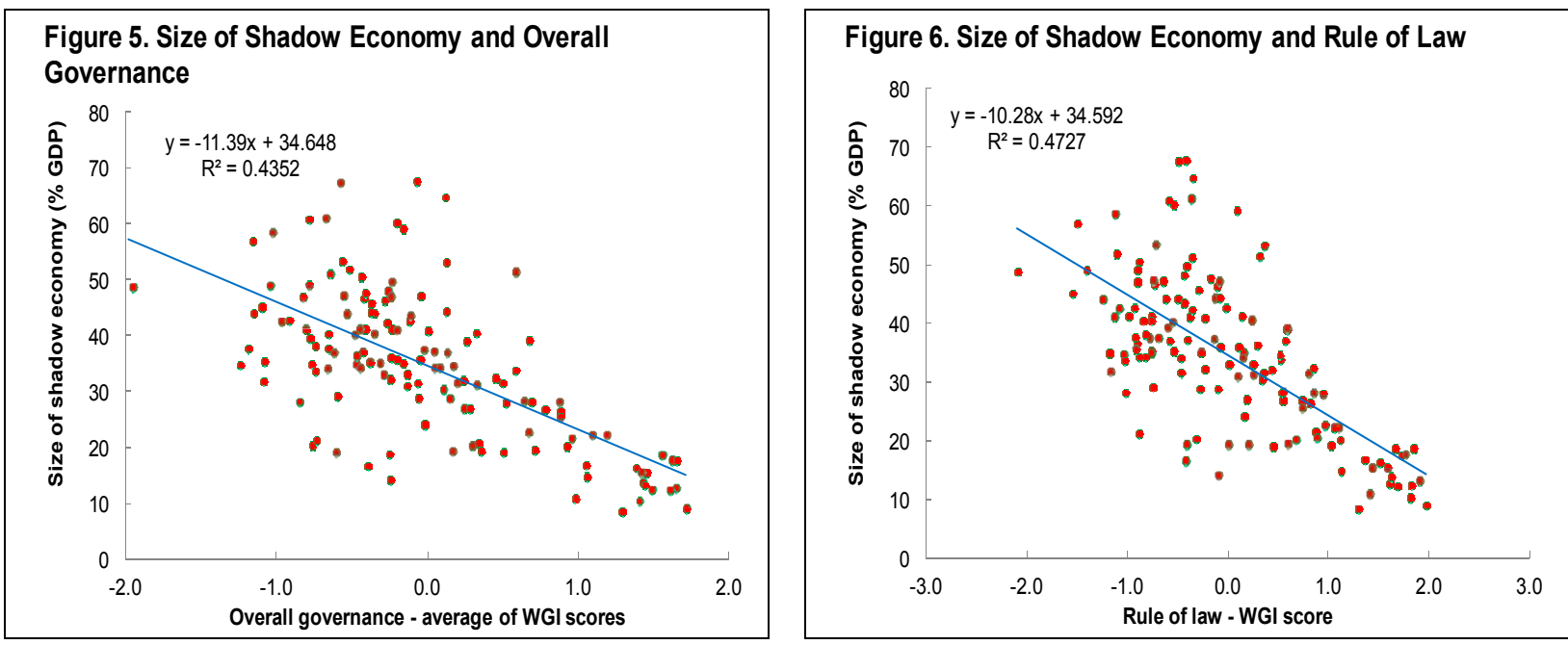

18. The main findings of the regression analysis are contained in Table 1 , and are as follows:

- $\quad$ Better institutions are associated with a significantly lower share of the shadow economy. If overall institutional quality improves by one standard deviation, an almost 11 percentage point reduction in the size of the shadow economy is achieved. Furthermore, a one standard deviation improvement in the rule of law score is associated with an 8 percentage point reduction in the share of the shadow economy. These results are robust across a number of different measures of institutional quality.

- $\quad$ Moreover, it is important to note that institutions are the most important determinant of the size of the underground economy. Once we control for institutions, taxes, inflation, and per capita income are no longer statistically significant. Therefore it is not higher taxes per se that leads to increased shadow economy but rather weak institutions and rule of law. Businesses have an incentive to go underground not to avoid high taxes but rather to reduce the burden of regulation, consistent with the 
findings of Friedman and others (2000).

Countries with more corruption tend to have larger underground economies. A one standard deviation decrease in the corruption index leads to a 7 percentage point increase in the size of the shadow economy.

Table 1. Determinants of the Size of the Shadow Economy

\begin{tabular}{|c|c|c|c|c|c|c|c|}
\hline $\begin{array}{l}\text { Dependent variable: size of } \\
\text { shadow economy (in percent of } \\
\text { GDP) } 1 /\end{array}$ & (1) & $(2)$ & (3) & $(4)$ & $(5)$ & (6) & $(7)$ \\
\hline Top marginal income tax rate $2 /$ & $-0.345^{*}$ & & $-0.300^{*}$ & $-0.234^{*}$ & -0.195 & -0.191 & -0.24 \\
\hline Inflation $3 /$ & & $0.674^{* *}$ & $0.828^{* *}$ & 0.059 & & & \\
\hline Per capita income (log) & & & & $-5.919^{* *}$ & -2.170 & -2.517 & -1.325 \\
\hline Rule of law 4/ & & & & & $-8.172^{*}$ & & \\
\hline Control of corruption 4/ & & & & & & $-7.077^{*}$ & \\
\hline Overall governance 5/ & & & & & & & $-10.725^{*}$ \\
\hline Constant & $45.578^{* *}$ & $27.615^{\star *}$ & $35.708^{* *}$ & $88.258^{* *}$ & $59.810^{* *}$ & $62.185^{*}$ & $55.639^{*}$ \\
\hline $\begin{array}{l}\text { Observations } \\
\text { R-squared }\end{array}$ & $\begin{array}{c}94 \\
0.099\end{array}$ & $\begin{array}{c}135 \\
0.117\end{array}$ & $\begin{array}{c}91 \\
0.259\end{array}$ & $\begin{array}{c}91 \\
0.523\end{array}$ & $\begin{array}{c}82 \\
0.576\end{array}$ & $\begin{array}{c}82 \\
0.572\end{array}$ & $\begin{array}{c}82 \\
0.558\end{array}$ \\
\hline
\end{tabular}

Notes and data sources:

Robust t-statistics in parentheses; ${ }^{* *} p<0.01,{ }^{*} p<0.05$.

${ }^{1}$ Average of estimates for 1999-2000, 2000-01, 2002-03, from Schneider (2005).

${ }^{2}$ Fraser Institute; data from the year 2000 .

${ }^{3} \mathrm{CPI}$ inflation in 2000.

${ }^{4}$ Kauffman, Kraay and Mastruzzi, World Bank 2009; data are average from 1996-2008.

${ }^{5}$ Overall institutional quality is measured as the averaged of six institutional variables as in KKM 2009.

\section{Conclusions}

\section{The underground economy constitutes a significant portion of the overall} economy in a number of countries. We find that when businesses are faced with onerous regulation and weak and inconsistent enforcement and corruption, they have an incentive to hide their activities in the underground economy. The findings also emphasize the importance of the rule of law in curbing shadow economic activity. The policy implication is that large reductions in tax rates or increasing the number of regulations will not shrink the shadow economy. Instead, governments should place emphasis on strengthening the rule of law, simplifying access to the formal economy, and on strict enforcement of the minimum necessary set of regulations, rather than increasing the plethora of regulatory requirements.

20. The IMF has been involved in strengthening economic institutions in the context of both the provision of surveillance advice and technical advice to members. Since the global recession, the IMF has played a key role in the reform of the financial regulatory and supervisory framework. Also in order to directly combat the problem of the underground 
economy, the IMF has been supporting members by providing technical assistance on combating money laundering and counter terrorist finance policy, and on larger governance and institutional issues when large illicit sectors are thought to be macro critical. 


\section{REFERENCES}

De Soto, H., 1989, "The Other Path: The Invisible Revolution in the Third World" (New York: Harper Collins).

Friedman, E, S. Johnson, D. Kaufmann, and P. Zoido-Lobaton, 2000, "Dodging the Grabbing Hand: the Determinants of Unofficial Activity in 69 Countries," Journal of Public Economics, Vol. 76, pp. 459-93.

Kaufmann, D., A. Kraay, and P. Zoido-Lobaton, 1999, "Aggregating Governance Indicators," Policy Research Working Paper Series 2195 (Washington: World Bank).

Kaufmann, D., A. Kraay, and M. Mastruzzi, 2009, "Governance Matters VIII: Aggregate and Individual Governance Indicators, 1996-2008,” World Bank Policy Research Working Paper No. 4978 (Washington: World Bank).

Schneider, F., 2004, "The Size of the Shadow Economies of 145 Countries all over the World: First Results over the Period 1999 to 2003" IZA Discussion Paper No. 1431. Available at SSRN: http://ssrn.com/abstract $=636661$

Schneider, F, A. Buehn, and C. Montenegro, 2010, "New Estimates for the Shadow Economies All Over the World," International Economic Journal, Vol. 24, No. 4, pp. 443-61.

Smith, P., 1994, Assessing the Size of the Underground Economy: the Statistics Canada Perspectives, Canadian Economic Observer, Vol. 7, No. 5.

World Bank, 2004, "Doing Business in 2005: Removing the Obstacles to Growth" (Washington: World Bank). 